\title{
SOCIODEMOGRAPHIC ASPECTS AND THEIR RELATIONSHIP WITH THE ECOTOURISTS' MOTIVATIONS IN A COASTAL NATIONAL PARK FROM ECUADOR
}

\author{
Mauricio CARVACHE-FRANCO* \\ Universidad Espíritu Santo-Ecuador, Samborondón, Km. 2.5 Vía a Samborondón, Ecuador, e-mail: mauricio2714@hotmail.com
}

Orly CARVACHE-FRANCO

Universidad Católica de Santiago de Guayaquil, Facultad de Especialidades Empresariales, Guayaquil, Km 1.5 Av.

Carlos Julio Arosemena, Ecuador, e-mail: orly.carvache@ cu.ucsg.edu.ec

Wilmer CARVACHE-FRANCO

Escuela Superior Politécnica del Litoral, ESPOL, Facultad de Ciencias Sociales y Humanísticas,

Campus Gustavo Galindo Km 30.5 Vía Perimetral, Guayaquil, Ecuador, e-mail: wcarvach@ espol.edu.ec

César VILLAGóMEZ-BUELE

Universidad de Guayaquil, Facultad de Ingeniería Química, Cdla. Universitaria Av. Delta y Av. Kennedy, Guayaquil, Ecuador, e-mail: cesar.villagomezb@ug.edu.ec

\author{
Andrea SALTOS-LAYANA \\ Universidad Tecnológica Empresarial de Guayaquil, UTEG, Facultad Online, Urdesa Central, \\ Guayacanes 520 y la Quinta, Guayaquil, Ecuador, e-mail: andrea.saltos.layana@gmail.com
}

\begin{abstract}
Citation: Carvache-Franco, M., Carvache-Franco, O., Carvache-Franco, W., Villagómez-Buele, C., Saltos-Layana, A. (2020). SOCIODEMOGRAPHIC ASPECTS AND THEIR RELATIONSHIP WITH THE ECOTOURISTS' MOTIVATIONS IN A COASTAL NATIONAL PARK FROM ECUADOR. GeoJournal of Tourism and Geosites, 31(3), 1075-1082. https://doi.org/10.30892/gtg.31320-543
\end{abstract}

\begin{abstract}
The following study analyzes the sociodemographic characteristics along with the motivations of ecotourists. The study was carried out in situ at the Machalilla National Park in Ecuador. A questionnaire was used and statistical techniques, such as Spearman's Correlation Coefficient, were employed; the results obtained contribute to the academic literature. Ecotourists are men and women whose main motivations are related to novelty, escape from the routine, and nature. Among the relationships of motivations and profile variables, older ecotourists have greater motivations for novelty and knowledge. The lower the level of education of tourists, the greater was their motivation for self-development and prestige/impression. Also, the lower the income levels of tourists, the greater their motivation for self-development and knowledge.
\end{abstract}

Key words: Ecotourism, nature, profile, sociodemography, motivation, Ecuador

$$
* \quad * \quad * \quad * \quad * \quad *
$$

\section{INTRODUCTION}

Tourism is an important source of local economic growth, which implies that knowing the tastes, preferences, and travel habits of tourists are truly relevant issues, to incorporate as technical criteria in the planning of public and private investment, and in the creation, innovation, or specialization of tourist products. Ecotourism can connect travelers to nature and help them develop stronger bonds with the natural world (Olmsted et al., 2020). Global conventions and reports emphasize the need to transform our relationship with nature if we are to sustain the ecosystem services and benefits we currently enjoy (Convention on Biological Diversity, 2019). Ecotourism is considered a sustainable mode of tourism that provides a solution to two major issues: poverty and biodiversity degradation (Cabral and Dhar, 2020). In this way, naturebased tourism in protected areas is an easily experienced ecosystem service that humans enjoy, but it acts as tourism pressures on ecosystem (Chun et al., 2020). Increasing environmental awareness broadens the perceived value of protected areas and ecological conservation, which in turn significantly contributes to the long-term development of ecotourism (Castellanos et al., 2016).

Ecuador is the second country in Latin America with the largest territory dedicated to the protection of its ecosystems, having $33.26 \%$ of its territory under conservation or environmental management (Ministry of Environment, 2016). Generally speaking, ecotourism models are increasingly recognized as a way to promote not only local livelihoods and culture but also environmental conservation as well (Kirkby et al., 2011). So far, little research has been done on the sociodemographic profile and motivations of people who visit National Parks in Ecuador, however, some global studies focus on this subject (Gundersen et al., 2015; Bhalla and Bhattacharya, 2019; Van der Merwe and Saayman, 2008).

The Machalilla National Park located in Ecuador is a protected area with natural and cultural attractions suitable for ecotourism, the park possesses both land and marine territory. Among its main attractions, several activities can be mentioned, such as sighting humpback whales, visiting the community of Agua Blanca, doing water sports like sailing, walking on ecological trails, and doing flora and fauna sightings. So far, no studies have been carried out analyzing the profile of the ecotourist and its sociodemographic aspects in the Machalilla National Park. Contributing with the results of this research to bridging the gap in the literature and to the creation of plans to benefit the sustainable development of a protected area. This study aims to analyze the relationship of sociodemographic and visiting aspects with the motivations of the tourist as this issue is crucial for the sustainability of a National Park. This information will serve as a bridge to understand the implications of the sociodemographic characteristics to facilitate the elaboration of development plans. Moreover, the results of the investigation will serve to improve the efficiency of the operation of the visitor management component of the ecotourism industry in Ecuador (Lee and Abrahams, 2018).

\footnotetext{
* Corresponding author
} 


\section{LITERATURE REVIEW}

Ecotourism, as part of sustainable tourism (Cater and Cater, 2015), has remained an important field for academic research since its inception, has been around in one form or another for about 30 years (McKercher, 2010; Weaver and Lawton, 2007). Many destinations and regions continue to develop and commercialize ecological and nature-related products in response to the growing demand for tourism products based on the environment (Castellanos et al., 2016; Walter, 2013). To develop a sustainable tourism, alternative models of this activity such as ecotourism, are increasingly being recognized as a way to promote not only local livelihoods and culture but also environmental conservation (Carvache-Franco et al., 2020; Kirkby et al., 2011). National parks are also important destinations for ecological and recreational tourism because they have almost unaltered environments and often with unique natural forms. In countries where the level of economic development is not satisfactory, one way of developing the tourism activity is by creating national parks (Bimonte and Punzo, 2016).

Motivation is considered as one of the most important variables to explain the behavior of a tourist during and after the trip. The results obtained in a study performed by Ma et al. (2018) on Chinese tourists visiting two protected areas in the Guangdong province, identified three motivational factors: Relaxation and exploration of nature, search for news, and social influence. Along these lines, Kamri and Radam (2013) carried out a survey to identify the reasons for visiting the Bako National Park, the results showed four aspects: challenge excursion, social trip, nature tour, and getaway. Wildlife tourism experiences and their overall satisfaction were the subjects of a study realized by Mutanga et al. (2017) where four push factors, to visit national parks in Zimbabwe, were identified. These factors were, recreation, the pursuit of knowledge, appreciate wildlife, and feel close to nature. Additionally, six pull factors were pinpointed as well, the abundance of wildlife, availability of different animal species, availability of different plant species, nature, beautiful scenery, and tranquility.

Ma et al. (2018) used the sociodemographic characteristics, motivation, and satisfaction to predict visit patterns and trip behaviors. Their findings demonstrated that the educational level is negatively correlated to tourist satisfaction, and motivation was also not correlated to social influence. Furthermore, they found that age is positively correlated to the feeling of relaxation and exploration of nature. In another study, Newton et al. (2018) examined the preferences of visitors to national parks related to the transportation attributes such as: waiting time at the entrance, parking availability, transit speed, and transit volume. Their results showed that there are significant differences between the choice of means of transportation and age.

The sociodemographic characteristics of tourists, such as age, level of education, and income, could be good predictors of their motivations since the association between these factors and motivation has been reported in previous findings. Regarding age, research has found that older people tend to be more motivated by "novelty" (Jönsson and Devonish, 2008). However, among the findings and observations of the study carried out by Luo and Deng (2008) on Chinese tourists, there was a negative correlation between age and the motivation for seeking novelty, indicating that younger tourists tend to look for more novelties. Along these lines, Kim et al. (2008) also suggested that young people are more motivated by the search for novelty than older people. For Carvache-Franco et al. (2018), the internet is the main information media that ecotourists use to find data about a protected area, followed by friends and acquaintances.

Regarding the level of education of tourists, Jensen (2015) suggested that the more educated visitors were more motivated by "relax and escape", "seek knowledge", and "socialization", while the less educated people were more associated with the factors of "prestige/impression" and "novelty". In this same income-related study, tourists in the highest-income groups rated "appreciation of nature" and "escape and relaxation" as a more important preference, while those in low-income groups showed a greater preference for the "search for knowledge". There are certain correlations between the variables sociodemographic and visitation, and the level of satisfaction. The study by Ozdemir et al. (2012) on tourist profiles and satisfaction in Turkey demonstrated that the tourists' characteristics of being a woman, elderly, highly educated, and with a low level of income were correlated with a higher level of satisfaction. Tsiotsou and Vasioti's (2006) study of demography and satisfaction with tourism services in Greece also supported the finding that older people with higher education levels tend to be more satisfied with their travel experiences. Barros and Machado (2010) reported that older, male and more educated visitors would probably have longer stays.

The research performed by Tepavčević et al. (2019) shows that the reasons for visiting and the limitations are different, depending on the sociodemographic characteristics of the respondents; they also indicated that the sociodemographic characteristics influence the reasons for the visit. This study partially confirmed the findings obtained by Ma et al. (2018), who used other variables but concluded that the sociodemographic characteristics have a significant impact on motivation to visit national parks.

Many sociodemographic profiles of people visiting national parks may be similar, however, it is considered appropriate to seg ment tourists from every park based on their preferences and motivations which is important for improved destination planning and management (Munien et al., 2019). This assertion is supported by Kim and Weiler (2013), who suggest that tourism managers should identify the differences between subgroups of tourists to nature-based destinations. Not only based on demographics and environmental attitudes, but also on their responses to visitor management approaches, for the correct interpretation of their wishes and preferences. These differences claim Kim and Weiler (2013), allow the destination to better adapt their communication messages, which should be informative, educational, and persuasive. Until now, the literature has not generalized concrete results on the relationship of sociodemographic aspects and their influence on other variables such as travel characteristics and motivations.

\section{STUDY AREA}

The Machalilla National Park is the main conservation area in the province of Manabí and it is part of the Natural Heritage of the Ecuadorian State (Manabí Provincial Government., 2015). It is located in the central-western area of the Coastal Region of Ecuador, in the southwest of the province of Manabí. The cantons involved in the park area are Jipijapa, Puerto López, and Montecristi.

According to the data supplied by the Ministry of the Environment (2015), Machalilla is a National Park that contains evidence of the ancient inhabitants of Manabí. Archaeological sites of various cultures are located within the National Park and in the surrounding areas. There are indications of the existence of the Valdivia culture which populated the region more than 5,000 years ago, or the ManteñoHuancavilca culture, who were inhabitants of the area around 500 years ago. Additionally, the National Park protects a great strip that goes from the top of the coastal mountain range of Chongón-Colonche to the marine environments that surround the Plata Island.

The Machalilla National Park is the only marine protected area in the Ecuadorian mainland, where the only coral reefs on the Ecuadorian coast are also found. It also has the greatest biodiversity in the coastal area and serves as a transit route for migratory fish. The fauna is composed of 81 species of mammals, 270 types of birds, and 143 species of fish. Its main attraction, with great demand of national and international tourists, is the sighting of humpback whales, which occurs from July to September of each year (Figure 1). 
The Ministry of the Environment (2015) mentions that among the main destinations and the tourist activities that take place within the Machalilla National Park are: a) Frailes Beach, located in López Port, considered one of the few beaches that still maintains its natural characteristics; b) The Plata Island is located 40 kilometers east of López Port. In this island tourists can watch birds and contemplate the cliffs of the island whose flora and fauna resemble that of the Galapagos Islands. In the surroundings of the Plata Island visitors can go snorkeling and observe the marine biodiversity. Several marine sports can be done here; c) Salango Beach, located 30 minutes from López Port, offers the opportunity to see the coral reef and enjoy the experience of surface diving or snorkeling. The gentle surf of this beach is ideal for water sports. Across from the beach is the islet of Salango where travelers can enjoy a spectacular view of native birds and exotic flora, typical of the marine environment; d) The Agua Blanca Commune, located 5 kilometers north of López Port, maintains an archaeological museum with pieces of the Manteño-Huancavilca culture. The famous stone chairs, also known as the chairs of power, have been found in this area, which has led archaeologists to consider that one of their ceremonial civic centers functioned there. There is a large pool of sulfurous waters in the community, the mud at the bottom of the pool offers magnificent relaxing properties.

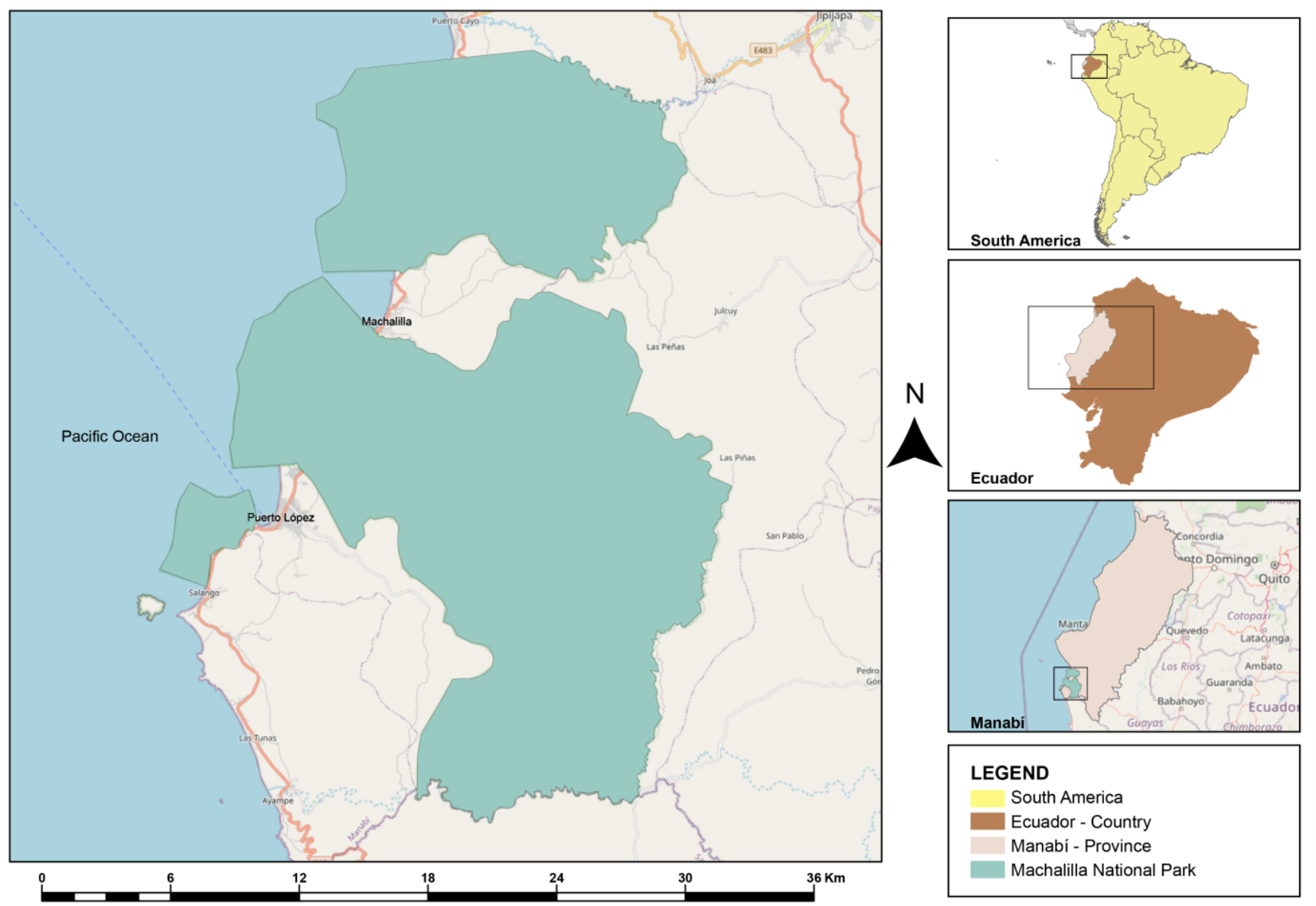

Figure 1. Geographical location of the Machalilla National Park, Ecuador

\section{METHODOLOGY}

For this investigation, a questionnaire was prepared based on several previous studies (Jensen, 2015; Kamri and Radam, 2013; Ma et al., 2018; Mutanga et al., 2017). The instrument consisted of two sections. In the first section, sociodemographic information, such as nationality, origin, gender, age, level of education, professional activity, and characteristics of the trip, company organizing the trip, length of stay, and expenditure on their stay, were collected. In the second section, the motivations, preferences, and tourist satisfaction were addressed. The questionnaire was designed with closed-ended questions and a five-point Likert scale to obtain reliable results.

The surveys were conducted on-site during August and September 2018. The interviewers, who were students from the University of Guayaquil (Ecuador), received training from the authors of this study. The data was collected, in the Machalilla National Park, during the moments in which the tourists carried out recreational activities or were resting. The tourists surveyed were adults, both nationals and foreigners who visited the studied ecotourism destination.

The statistical data collected was organized, tabulated, and analyzed using the SPSS version 22 software. The sample was composed of 386 valid surveys, and the infinite population was used. With the sample reached, the study was performed with a $+/-5 \%$ margin of error, a confidence level of $95 \%$, and a variability of $50 \%$. (Table1).

Table 1. Research methodology

\begin{tabular}{|l|l|}
\hline Population & National and foreign visitors \\
\hline Geographic area & Machalilla National Park (Ecuador) \\
\hline Period of completion & August to September 2018 \\
\hline Procedure & Simple random sampling \\
\hline Confidence level & $95 \%$ \\
\hline Margin of error & $+/-5 \%$ \\
\hline Valid questionnaires & 386 \\
\hline
\end{tabular}




\section{RESULTS AND DISCUSSION}

For a better understanding, the results of the study have been divided into several sections to analyze the sociodemographic aspects of the ecotourists and their relationship with motivations.

Sociodemographic aspects

The aspects of the tourists' profile and the characteristics of the ecotourist trip are shown in Table 2. 75.6\% of respondents claimed to be national tourists and $24.4 \%$ to be foreign. The majority of the people interviewed said they are from South America (85.8\%) followed by those from a European origin (10.9\%). 59\% of tourists were female and $41 \%$ male. The largest age group was made up by the 20 to 29 years of age with $42 \%$, followed by the 30 to 39 years of age group with $28.2 \%$ and the group ranging from 40 to 49 amounted to $13 \%$ of the sample, indicating that their ages were generally between 20 and 39, so they were young adults. The visitors' level of training was mainly university education (61.9\%), followed by the group with secondary education (21.85), which establishes a good educational level among ecotourists.

Regarding their professional activity, the majority group was composed of private employees (28.5\%), followed by students ( $24.9 \%)$ and public employees (14.2\%), so there is a variety of productive activities in their profiles. The ecotourists surveyed mostly traveled with their family $(56 \%)$, with their friends $(28.2 \%)$, and with a partner $(10.9 \%)$, which means that they generally visited the protected areas in the company of other people. The daily expenditure in this National Park was mainly less than $\$ 30$ which is $23.8 \%$ of the sample, followed by the $\$ 30$ to $\$ 40$ range with a percentage of 23.6 , establishing this as the average spending by ecotourists per day. As for the visitors' monthly income, $36 \%$ of interviewed tourists asserted to have an income of less than $\$ 500$, followed by $28.2 \%$ who affirmed to receive a wage in the $\$ 501$ and \$ 1,000 range. It was also found that $5.4 \%$ earn above \$3,000, so their incomes were varied (Table 2).

Table 2. Sociodemographic aspects and characteristics of the trip

\begin{tabular}{|c|c|c|c|}
\hline Sociodemography & Category & $N=386$ & $\%$ \\
\hline \multirow[t]{2}{*}{ Origin } & National & 292 & 75.6 \\
\hline & Foreign & 94 & 24.4 \\
\hline \multirow[t]{5}{*}{ Origin by continent } & North America & 8 & 2.1 \\
\hline & Europe & 42 & 10.9 \\
\hline & South America & 331 & 85.8 \\
\hline & Asia & 2 & 0.8 \\
\hline & Rest of the world & 5 & 0.5 \\
\hline \multirow[t]{2}{*}{ Gender } & Male & 158 & 41 \\
\hline & Female & 227 & 59 \\
\hline \multirow[t]{6}{*}{ Age } & $<20$ & 26 & 6.7 \\
\hline & 20 to 29 years old & 162 & 42 \\
\hline & 30 to 39 years old & 109 & 28.2 \\
\hline & 40 to 49 years old & 50 & 13 \\
\hline & 50 to 59 years old & 29 & 7.5 \\
\hline & $>59$ years old & 10 & 2.6 \\
\hline \multirow[t]{4}{*}{ Education level } & Primary & 6 & 1.6 \\
\hline & Secondary & 84 & 21.8 \\
\hline & University & 239 & 61.9 \\
\hline & Postgraduate / Master / PhD & 57 & 14.8 \\
\hline \multirow[t]{9}{*}{ Professional activity } & \begin{tabular}{|l|} 
Student \\
\end{tabular} & 96 & 24.9 \\
\hline & Researcher / Scientist & 16 & 4.1 \\
\hline & Entrepreneur / Business owner & 33 & 8.5 \\
\hline & Private employee & 110 & 28.5 \\
\hline & Public employee & 55 & 14.2 \\
\hline & Housework & 16 & 4.1 \\
\hline & Unemployed & 10 & 2.6 \\
\hline & Retired & 8 & 2.1 \\
\hline & Informal worker & 10 & 2.6 \\
\hline \multirow[t]{4}{*}{ Who you visit with } & Alone & 15 & 3.9 \\
\hline & With family & 216 & 56 \\
\hline & With friends & 109 & 28.2 \\
\hline & With a partner & 42 & 10.9 \\
\hline \multirow[t]{7}{*}{ Monthly income } & $<\$ 500$ & 139 & 36.0 \\
\hline & $\$ 501-\$ 1,000$ & 109 & 28.2 \\
\hline & $\$ 1,001-\$ 1,500$ & 53 & 13.7 \\
\hline & $\$ 1,501-\$ 2,000$ & 40 & 10.4 \\
\hline & $\$ 2,001-\$ 2,500$ & 15 & 3.9 \\
\hline & $\$ 2,501-\$ 3,000$ & 9 & 2.3 \\
\hline & $>\$ 3,000$ & 21 & 5.4 \\
\hline \multirow[t]{6}{*}{ Daily expenditure } & $<\$ 30$ & 92 & 23.8 \\
\hline & $\$ 30.1-\$ 40$ & 91 & 23.6 \\
\hline & $\$ 40.1-\$ 50$ & 72 & 18.7 \\
\hline & $\$ 50.1-\$ 60$ & 40 & 10.4 \\
\hline & $\$ 60.1-\$ 70$ & 36 & 9.3 \\
\hline & $>\$ 70$ & 55 & 14.2 \\
\hline
\end{tabular}

To obtain data regarding the sources of information visitors consulted before visiting the Machalilla National Park, a Likert scale from 1 to 5 ( 1 being not at all important and 5 being very important) was used. The results show that the main information media used by ecotourists was the Internet with a mean of 3.98, followed by social networks with 3.85, and friends and acquaintances with 3.57 , results which are similar to those obtained by Carvache-Franco et al. (2018) (Table 3). 
Table 3. Information sources

\begin{tabular}{|c|c|c|c|c|c|}
\hline Variables & $\mathbf{N}$ & Minimum & Maximum & Means & Standard Desv. \\
\hline Internet & 386 & 1 & 5 & 3.98 & 1.296 \\
\hline Social networks & 386 & 1 & 5 & 3.85 & 1.415 \\
\hline Friends and acquaintances & 386 & 1 & 5 & 3.57 & 1.411 \\
\hline Official sources of tourist information & 386 & 1 & 5 & 3.02 & 1.508 \\
\hline Communication media specialized in tourism & 386 & 1 & 5 & 2.97 & 1.496 \\
\hline Advertising & 386 & 1 & 5 & 2.9 & 1.543 \\
\hline Travel guides & 386 & 1 & 5 & 2.78 & 1.488 \\
\hline Information on suppliers and intermediaries & 386 & 1 & 5 & 2.76 & 1.443 \\
\hline Opinion leaders & 386 & 1 & 5 & 2.75 & 2.251 \\
\hline Trade shows & 386 & 1 & 5 & 2.62 & 1.535 \\
\hline Documentaries & 386 & 1 & 5 & 2.58 & 1.456 \\
\hline Movies and TV series & 386 & 1 & 5 & 2.43 & 2.143 \\
\hline Books & 386 & 1 & 5 & 2.35 & 1.371 \\
\hline
\end{tabular}

\section{Motivations}

A 5-point Likert scale (where 1 is a little and 5 is a lot) was used to analyze the motivations ecotourists presented to visit this protected area.

Table 4. Motivations of the ecotourist

\begin{tabular}{|c|c|c|c|c|c|}
\hline Motivations & $\mathbf{N}$ & Minimum & Maximum & Means & $\begin{array}{c}\text { Standard } \\
\text { Desv. }\end{array}$ \\
\hline To have fun & 386 & 1 & 5 & 4.48 & 0.797 \\
\hline To experience new things & 386 & 1 & 5 & 4.34 & 0.912 \\
\hline To escape the routine & 386 & 1 & 5 & 4.33 & 1.020 \\
\hline To better appreciate nature & 386 & 1 & 5 & 4.31 & 0.909 \\
\hline To obtain good memories & 386 & 1 & 5 & 4.29 & 0.992 \\
\hline To get away from daily stress & 386 & 1 & 5 & 4.25 & 1.108 \\
\hline To be close to nature & 386 & 1 & 6 & 4.23 & 1.015 \\
\hline To explore the unknown & 384 & 1 & 5 & 4.22 & 1.000 \\
\hline To feel harmony and inner peace & 386 & 1 & 5 & 3.93 & 1.254 \\
\hline To avoid interpersonal stress & 386 & 1 & 5 & 3.92 & 1.333 \\
\hline To experience different cultures & 386 & 1 & 5 & 3.9 & 1.147 \\
\hline To be away from crowds & 386 & 1 & 5 & 3.84 & 1.307 \\
\hline To develop my personal interests & 386 & 1 & 5 & 3.74 & 1.278 \\
\hline To meet new people & 386 & 1 & 5 & 3.68 & 1.267 \\
\hline To know the destination & 386 & 1 & 5 & 3.67 & 1.426 \\
\hline To strengthen the relationship with my family & 386 & 1 & 6 & 3.59 & 1.466 \\
\hline To unite the interest of the people & 386 & 1 & 5 & 3.53 & 1.409 \\
\hline To obtain a sense of self-realization & 386 & 1 & 5 & 3.53 & 1.321 \\
\hline To obtain a new perspective on life & 386 & 1 & 5 & 3.51 & 1.331 \\
\hline To meet the inhabitants of the place & 386 & 1 & 5 & 3.5 & 1.312 \\
\hline To have the opportunity to get to know me better & 386 & 1 & 5 & 3.46 & 1.339 \\
\hline To meet people with similar interests & 386 & 1 & 15 & 3.42 & 1.415 \\
\hline To have a sense of self-confidence & 386 & 1 & 5 & 3.38 & 1.402 \\
\hline To think about the good times I have had in the past & 386 & 1 & 5 & 3.36 & 1.406 \\
\hline To understand more about myself & 386 & 1 & 5 & 3.36 & 1.344 \\
\hline To be independent & 386 & 1 & 5 & 3.29 & 1.421 \\
\hline To contact family friends who live elsewhere & 386 & 1 & 5 & 3.28 & 1.511 \\
\hline To find out what I am capable of & 386 & 1 & 5 & 3.25 & 1.394 \\
\hline To follow current events & 385 & 1 & 5 & 3.22 & 1.476 \\
\hline To reflect on memories from the past & 386 & 1 & 5 & 3.15 & 1.524 \\
\hline To join the social discussion & 386 & 1 & 5 & 3.12 & 1.438 \\
\hline To feel that I belong & 385 & 1 & 5 & 3.1 & 1.475 \\
\hline To remember the times with parents & 386 & 1 & 5 & 3.07 & 1.516 \\
\hline To be with others if I need them & 386 & 1 & 5 & 3.04 & 1.373 \\
\hline
\end{tabular}

As shown in Table 4, the main motivations of tourists are to have fun (with a score of 4.48), to experience new things (with a score of 4.34), to escape from the routine (with a score of 4.33) and for appreciating nature better (with a score of 4.31). These results are similar to those reported by Ma et al. (2018) who identified three motivating factors, Relaxation and exploration of nature, Search for news, and Social influence.

Relationship between age and motivations

Spearman's Correlation Coefficient was used to find associations between age and motivations.

Table 5. Relationship between age and motivations (Spearman's Correlation Coefficient)

\begin{tabular}{|l|c|c|}
\hline Motivational variable & Coefficient & Sig. \\
\hline To meet local people & 0.138 & 0.006 \\
\hline To know the destination & 0.105 & 0.039 \\
\hline To follow current events & 0.104 & 0.042 \\
\hline To meet new people & 0.102 & 0.046 \\
\hline
\end{tabular}


As shown in Table 5, the variables that presented a correlation with age are to meet local people (coefficient $=0.138$ ), to know the destination (coefficient $=0.105)$, to follow current events $($ coefficient $=0.104)$ and to meet new people $($ coefficient $=0.102)$. All these variables are related to novelty and knowledge. Therefore, the greater motivation in older tourists is to get to know the inhabitants of the place, to know the destination, to follow current events, and to meet new people. In other words, the older the tourists, the greater their motivation is for novelty and knowledge in this protected area. Similar results were reported by Jönsson and Devonish (2008) who mentioned that older people tend to be more motivated by "novelty".

\section{Relationship of education level and motivations}

To find the associations between the level of education and motivations, the Spearman's Correlation Coefficient was used.

According to Table 6, the variables that had the highest negative correlation with the level of education of the tourists were, to reflect on the memories from the past (correlation $=-0.153$ ), to obtain a new perspective of life (correlation $=-0.140$ ), to have a sense of selfconfidence (correlation $=-0.128$ ), and to understand more about myself (correlation $=-0.116$ ). All these motivational variables are related to self-development and prestige/impression. Therefore, the lower the level of education of tourists, the greater was their motivation for selfdevelopment and prestige/impression. On the contrary, the higher the level of education of tourists, the lower was their motivation for selfdevelopment and prestige/impression. These results concur with the outcomes from Jensen (2015), who asserted that less educated people were more associated with the "prestige/impression" and "novelty" factors.

Table 6. Relationship between education level and motivations (Spearman's Correlation Coefficient)

\begin{tabular}{|l|c|c|}
\hline Motivational variables & Coefficient & Sig. \\
\hline To reflect on memories from the past & -0.153 & 0.003 \\
\hline To obtain a new perspective on life & -0.140 & 0.006 \\
\hline To have a sense of self-confidence & -0.128 & 0.012 \\
\hline To understand me more & -0.116 & 0.022 \\
\hline To feel that I belong & -0.117 & 0.117 \\
\hline To be away from the crowds of people & -0.117 & 0.021 \\
\hline To have the opportunity to know me better & -0.115 & -0.105 \\
\hline To remember the times with parents & -0.102 & \\
\hline To follow current events & -0.101 & 0.039 \\
\hline To know what I am capable of & -0.101 & 0.045 \\
\hline To feel harmony and inner peace & 0.048 & 0.047 \\
\hline
\end{tabular}

Relationship between income level and motivations

Spearman's Correlation Coefficient was used to find the associations between income level and motivations.

Table 7. Relation between income level and motivations (Spearman's Correlation Coefficient)

\begin{tabular}{|c|c|c|}
\hline Motivational variables & Coefficient & Sig. \\
\hline To have the opportunity to know me better & -0.121 & 0.017 \\
\hline To understand myself more & -0.151 & 0.003 \\
\hline To obtain a new perspective of life & -0.211 & 0.000 \\
\hline To think about the good times I have had in the past & -0.155 & 0.002 \\
\hline To know what I am capable of & -0.154 & 0.002 \\
\hline To have a sense of self-confidence & -0.163 & 0.001 \\
\hline To feel harmony and inner peace & -0.108 & 0.034 \\
\hline To remember the times with the parents & -0.116 & 0.022 \\
\hline To contact family and friends living in other places & -0.125 & 0.014 \\
\hline To feel that I belong & -0.113 & 0.027 \\
\hline To reflect on the memories from the past & -0.119 & 0.019 \\
\hline
\end{tabular}

According to Table 7, the variables that were found to be more negatively correlated with the tourists' income level, to have the opportunity to get to know me better (correlation $=-0.121$ ), to understand myself more (correlation $=-0.151$ ), to get a new perspective on life (correlation $=-0.211$ ) and to think about the good times I've had in the past (correlation $=-0.155)$. All these motivational variables are related to self-development and knowledge. It can then be concluded that the lower the income level of tourists, the greater their motivation for self-development and knowledge. On the contrary, the higher the income level of tourists, the lower was their motivation for self-development and knowledge. Results that are consistent with what Jensen (2015) reported saying that low-income tourists demonstrated a greater motivation for the "search for knowledge".

\section{CONCLUSION}

National parks located in coastal areas offer a variety of ecotourism activities, both terrestrial and marine. Ecotourists se arch for nature and culture in a national park with their family and friends. Due to these conditions, it is important to establish the sociodemographic characteristics of ecotourists to understand their motivations and develop management policies that preserve the environment of these destinations. Among the sociodemographic aspects of ecotourists who visit a coastal National Park, it can be mentioned that they are found to be men and women, generally young adults, with a good educational level, a varied professional activity, and they generally travel accompanied by their family, friends, or a partner. They have a daily expenditure of between $\$ 30$ and $\$ 50$ a day. Besides, they have several incomes, mostly between $\$ 500$ and $\$ 1,000$ a month. Furthermore, they obtain their information about protected areas through the internet, social networks, and friends and acquaintances.

The main motivations of ecotourists are related to novelty, escape from the routine and, nature. Among the relationships of motivations and profile variables in ecotourism destinations, it is noted that older tourists have greater motivations for novelty and 
knowledge. In contrast, less educated tourists have higher motivations related to self-development and prestige/impression. On the other hand, tourists with low-income levels have greater motivations for self-development and knowledge.

Regarding the theoretical implications, this study contributes to the literature with the findings that indicate the existence of three motivating factors: relaxation and exploration of nature, search for news, and social influence, similar to what was reported by Ma et al. (2018). Older people are often more motivated by "novelty", similar to what Jönsson and Devonish (2008) concluded. Less educated people were more associated with "prestige/impression" and "novelty" factors; and low-income tourists were more motivated by the "search for knowledge", results which are analogous to Jensen's (2015).

As practical implications, this work serves for tourism-related institutions to have information on the profile and motivations of ecotourists. In this way, efficient marketing policies and plans can be plated focusing on improving the sustainability of the destination and the care of the natural area, bringing benefits to the destination, the community, and the tourist. Finally, the main limitation of the present study was the timing in which the sample was taken because the demand may vary. As a future line of research, it would be interesting to carry out a study of the economic impact of the ecotourist in a coastal national park concerning environmental care.

\section{REFERENCES}

Barros, C.P., \& Machado, L.P. (2010). The length of stay in tourism. Annals of Tourism Research,37(3), 692-706. https://doi.org/10.1016/j.annals. 2009.12.005

Bhalla, P., \& Bhattacharya, P. (2019). Visitors' satisfaction from ecotourism in the protected area of the Indian Himalayan Region using importanceperformance analysis. Journal of Global Scholars of Marketing Science, 29(2), 162-179. https://doi.org/10.1080/21639159.2019.1577157

Bimonte, S., \& Punzo, L.F. (2016). Tourist development and host-guest interaction: An economic exchange theory. Annals of Tourism Research, 58, 128-139. https://doi.org/10.1016/j.annals.2016.03.004

Cabral, C., \& Dhar, R.L. (2020). Ecotourism research in India: From an integrative literature review to a future research framework. Journal of Ecotourism, 19(1), 23-49. https://doi.org/10.1080/14724049.2019.1625359

Carvache-Franco, M., Carvache-Franco, O., \& Carvache-Franco, W. (2020). Exploring the Satisfaction of Ecotourism in Protected Natural Areas. GeoJournal of Tourism and Geosites, 29 (2), 672-683. https://doi.org/10.30892/gtg.29223-498

Carvache-Franco, M., Carvache-Franco, O., Solis-Radilla, M.M., \& Carvache-Franco, W. (2019). The perceived value and profile of protected areas visitors: A case study of the Guayas province, Ecuador. Geographica Pannonica, 23(2), 135-147. https://doi.org/10.5937/gp23-20582

Castellanos-Verdugo, M., Vega-Vázquez, M., Oviedo-García, M.Á., \& Orgaz-Agüera, F. (2016). The relevance of psychological factors in the ecotourist experience satisfaction through ecotourist site perceived value. Journal of Cleaner Production, 124, 226-235. https://doi.org/10.1016/j.jclepro. 2016.02.126

Cater, C., \& Cater, E. (2015). Ecotourism. In J. D. Wright (Ed.), International encyclopedia of the social \& behavioral sciences (pp. 105-109). eBook, Elsevier Publishing.

Chun, J., Kim, C.K., Kim, G.S., Jeong, J., \& Lee, W.K. (2020). Social big data informs spatially explicit management options for national parks with high tourism pressures. Tourism Management, 81, 104136. https://doi.org/10.1016/j.tourman.2020.104136

Gundersen, V., Mehmetoglu, M., Vistad, O.I., \& Andersen, O. (2015). Linking visitor motivation with attitude towards management restrictions on use in a national park. Journal of Outdoor Recreation and Tourism, 9, 77-86. https://doi.org/10.1016/j.jort.2015.04.004

Jensen, J. M. (2015). The relationship between socio-demographic variables, travel motivations and subsequent choice of vacation. Advances in Economics and Business, 3(8), 322-328. https://doi.org/10.13189/aeb.2015.030804

Jönsson, C., \& Devonish, D. (2008). Does nationality, gender, and age affect travel motivation? A case of visitors to the Caribbean island of Barbados. Journal of Travel \& Tourism Marketing, 25(3-4), 398-408. https://doi.org/10.1080/10548400802508499

Kamri, T., \& Radam, A. (2013). Visitors' Visiting Motivation: Bako National Park, Sarawak. Procedia - Social and Behavioral Sciences, 101(8), 495-505. https://doi.org/10.1016/j.sbspro.2013.07.223

Kim, A.K.J., \& Weiler, B. (2013). Visitors' attitudes towards responsible fossil collecting behaviour: An environmental attitude-based segmentation approach. Tourism Management, 36, 602-612. https://doi.org/10.1016/j.tourman.2012.08.005

Kim, S.S., Kim, M., Park, J., \& Guo, Y. (2008). Cave tourism: Tourists' characteristics, motivations to visit, and the segmentation of their behavior. Asia Pacific Journal of Tourism Research, 13(3), 299-318. https://doi.org/10.1080/10941660802280448

Kirkby, C.A., Giudice, R., Day, B., Turner, K., Soares-Filho, B.S., Oliveira-Rodrigues, H., \& Yu, D.W. (2011). Closing the ecotourism-conservation loop in the Peruvian Amazon. Environmental Conservation, 38(1), 6-17. https://doi.org/10.1017/S0376892911000099

Lee, A.K.Y., \& Abrahams, R.A. (2018). Naturalizing people, ethnicizing landscape: Promoting tourism in China's rural periphery. Asian Geographer, 35(2), 177-196.https://doi.org/10.1080/10225706.2018.1505646

Luo, Y., \& Deng, J. (2008). The New Environmental Paradigm and nature-based tourism motivation. Journal of Travel Research, 46(4), 392-402. https://doi.org/10.1177/0047287507308331

Ma, A., Chow, A., Cheung, L., Lee, K., \& Liu, S. (2018). Impacts of Tourists' Sociodemographic Characteristics on the Travel Motivation and Satisfaction: The Case of Protected Areas in South China. Sustainability, 10(10), 3388. https://doi.org/10.3390/su10103388

McKercher, B. (2010). Academia and the evolution of ecotourism. Tourism Recreation Research, 35(1), 15-26. https://doi.org/10.1080/02508281.2010.11081615

Munien, S., Gumede, A., Gounden, R., Bob, U., Gounden, D., \& Perry, N.S. (2019). Profile of visitors to coastal and marine tourism locations in Cape Town, South Africa. GeoJournal of Tourism and Geosites, 27(4), 1134-1147. https://doi.org/10.30892/gtg.27402-421

Mutanga, C.N., Vengesayi, S., Chikuta, O., Muboko, N., \& Gandiwa, E. (2017). Travel motivation and tourist satisfaction with wildlife tourism experiences in Gonarezhou and Matusadona National Parks, Zimbabwe. Journal of outdoor recreation and tourism, 20, 1-18. https://doi.org/10.1016/j.jort.2017.08.001

Newton, J.N., Newman, P., Taff, B.D., Shr, Y.H., Monz, C., \& D’Antonio, A. (2018). If I can find a parking spot: A stated choice approach to Grand Teton National Park visitors' transportation preferences. Journal of Outdoor Recreation and Tourism. Advance online Publication. https://doi.org/10. 1016/j.jort.2018.04.001

Olmsted, P., Honey-Rosés, J., Satterfield, T., \& Chan, K.M. (2020). Leveraging support for conservation from ecotourists: can relational values play a role?. Journal of Sustainable Tourism, 28(3), 497-514. https://doi.org/10.1080/09669582.2019.1683184

Ozdemir, B., Aksu, A., Ehtiyar, R., Çizel, B., Çizel, R.B., \& İçigen, E.T. (2012). Relationships among tourist profile, satisfaction and destination loyalty: Examining empirical evidences in Antalya region of Turkey. Journal of Hospitality Marketing \& Management, 21(5), 506-540. https://doi.org/10.1080/ 19368623.2012 .626749 
Tepavčević, J., Miljanić, U., Bradić, M., \& Janićević, S. (2019). Impact of London residents' sociodemographic characteristics on the motives for visiting national parks. Journal of the Geographical Institute "Jovan Cvijic", SASA, 69(2), 135-146. https://doi.org/10.2298/IJGI1902135T

Tsiotsou, R., \& Vasioti, E. (2006). Using demographics and leisure activities to predict satisfaction with tourism services in Greece. Journal of Hospitality \& Leisure Marketing, 14(2), 69-82. https://doi.org/10.1300/J150v14n02_05

Van der Merwe, P., \& Saayman, M. (2008). Travel Motivations of Tourists Visiting Kruger National Park. African Protected Area Conservation and Science, 50(1), 154-159. https://doi.org/10.4102/koedoe.v50i1.140

Walter, P.G. (2013). Theorising visitor learning in ecotourism. Journal of Ecotourism, 12(1), 15-32. https://doi.org/10.1080/14724049.2012.742093

Weaver, D.B., \& Lawton, L.J. (2007). Twenty years on: The state of contemporary ecotourism research. Tourism Management, 28(5), 1168-1179. https://doi.org/10.1016/j.tourman.2007.03.004

*** Convention on Biological Diversity. (2019). Post 2020 Global Biodiversity Framework: Discussion Paper. www.cbd.int

*** Manabí Provincial Government. (2015) Development and territorial planning plan with special emphasis on Heritage of Natural Areas of Ecuador (PANE).

*** Ministry of the Environment (2015). National System of Protected Areas of Ecuador (SNAP), Machalilla National Park. http://areasprotegidas.ambiente. gob.ec/es/areas-protegidas/parque-nacional-machalilla

*** Ministry of the Environment (2016). Protected areas of Ecuador strategic partner for development. http://suia.ambiente.gob.ec/documents/10179/346525/ Areas+Protegidas+del+Ecuador.pdf/390b099f-6f57-4d38-bf17-cea3a138caf5

Accepted: 07.08.2020

Available online: 11.09.2020 